$391 \mathrm{ff})$. Despite these criticisms the book is cvidently as worth having as it was worth writing.

Frank N. Trager

Professor of International Affairs

Acting Director, Center for

International Affairs and

Development

New York University

Walter Ruben (Ed.). Die Ökonomische und Soziale Entwicklung Indiens: Sowjetische Beitrage zur Indischen Geschichte. Pp. $\mathrm{x}, 308$. Berlin: Akademie Verlag, 1959. DM 22.00.

This book contains a collection of eleven papers by various Soviet authors on the social and economic history of India, mostly since the onset of British rule. Only two essays deal with the pre-Muslim and Muslim period. The papers vary greatly in quality, and one or two are extremely poor and seem to have been included mainly for their ideological undertone.

The underlying purpose of all papers is to show that India since the eleventh century has passed through a period of "feudalism," which by the end of the nineteenth century gradually came to be replaced by "capitalism." Moreover, the attempt is made to show that the "lower forms of capitalist enterprise" are gradually losing out to the factory, that is, the cottage industries and small enterprises tend to be replaced by larger firms. In brief, the papers in this book are designed to clarify the Marxian theory of capitalist development, and this framework clearly stands out-including especially Marxian terminology as well as numerous references to often unrelated works of Marx and Lenin.

If we disregard the statements of doctrine and the special Marxian terminology, we have--except for a few papers-a number of quite competent essays on recent economic history of India. The sources used by the Soviet authors are the same as those employed by Western scholars: they are mostly settlement reports, accounts of travelers, parliamentary papers, district gazetteers, and documents of the East India Company. Of course, the data extracted from these sources by the Soviet scholars are designed to show the nature of feudal, and particularly capitalist, exploitation of the Indian peasants and workers by the landed aristocracy and the industrial and financial bourgeoisie.

This book is an interesting example of Soviet historical writing, at about the end of the Stalinist era. Though it is, on the one hand, infested with a strong doctrinaire bias, it presents, on the other, a host of interesting and well-documented data from Indian economic history and draws attention to some otherwise little explored aspects of the Indian economy mainly in the eighteenth and nineteenth centuries. In particular, the discussion of village communities in Maharashtra in the early nineteenth century, the early phases of the zamindari system under the East India Company in Bengal, and the problems of tenancy relations in Tamilnad in the interwar period repay study. Anyone who reads German with some ease will find it interesting to browse in this book, in part for the substantive problems discussed there, and in part to examine the way in which orthodox Soviet historiography deals with the economic history of an underdeveloped country of Asia.

\section{Professor of Social Sciences}

University of Chicago

\section{K. P. Bhagat. A Decade of Indo-British} Relations, 1937-47. Pp. xv, 521. Bombay: Popular Book Depot, 1959. Rs. 25.00 .

The last decade of British rule in India was one of great importance in forming and hardening the political conditions that have prevailed in India since 1947. The period encompassed the inauguration of the 1935 Act, the experimental provincial governments (1937-1939), wartime politics, the rapid rise of the Pakistan demand; finally, partition and independence. Professor Bhagat has addressed himself to an analysis of this crucial period.

Unfortunately, the author has not contributed much to a better understanding of the decade. Relying heavily on the admirable series of "Annuals" edited by N. N. Mitra, with scattered additions of evidence from a number of other standard 
sources, Professor Bhagat has outlined in tiresome detail, and with hundreds of truncated quotations, a week-by-week review of the critical political issues of the times. As a reference, the book is not always reliable; the analysis and interpretation are lacking in insight and objectivity. For one case, the Pakistan issue is not fairly treated, unless one accepts the official Congress stand uncritically.

For some curious reason, the phrase "... it was this dynamic nationalism which was one of the most potent factors that demanded British withdrawal from India ..." (p. 37), or paraphrases of the same thought, reappears in the book over thirty times by my count-repeated three times on page 62 alone! There are several other similarly questionable clichés that, used over and over, tend to round out this 521page book.

This book represents a serious attempt by an Indian scholar to use careful techniques of documentation and footnoting, no doubt impressed on him in his graduate training in the United States. There is nothing wrong with these techniques, properly used. But content, insight, and relevance surely must come first. Despite the enormous amount of work that appears to have been poured into the preparation of this study, the result cannot be commended.

The Index is generally good, as is the organizational layout of the book. Typographical errors abound.

Richard L. PARK

Associate Professor of Political

Science

University of Michigan

Frank Moraes. The Revolt in Tibet. Pp. 223. New York: The Macmillan Company, 1960. $\$ 3.95$.

This book is one of the best popular descriptions of the Chinese subjection of Tibet during the period from 1950 to 1959. The author, an Indian journalist and scholar who is well known for his books on Mao's China and on Nehru, combines in this. well-written book the documentary evidence of treaties and agreements with the personal accounts of participants including that of the Dalai Lama himself.
The book begins with an account of the flight of the Dalai Lama from Ihasa and then deals with the historical background of Sino-Tibetan relations and of India's role in the present tragedy of Tibet. It is interesting because of the critical view taken by an Indian observer of Nehru's actions and policies.

In discussing the Indian responsibility for the seventeen-point agreement which the Tibetans were forced to sign in 1951 and the agreement between India and China of 1954, the author points out the inconsistency of Nehru in claiming that he had to follow the British acceptance of Chinese suzerainty or overlordship over Tibet without insisting on any practical guarantees for Tibetan autonomy. For Nehru there was no difference between sovereignty and suzerainty, and he was most vague about the legal consequences of Chinese control which according to him had existed unchallenged over the last several hundred years. By accepting in the the treaty of 1954 the Chinese phrase "the Tibet region of China" Nehru had gone far beyond anything the British had ever recognized and thus, in the author's view, not only accepted what actually was a British "imperialist" concept but had given away, without consulting the Tibetan government, any legal basis for challenging China's breach of the treaty she had signed with Tibet.

One weakness of this most informative book may be found in its organization. The author changes from accounts of present events to descriptions of history and back again. Material on events in Tibet alternates with material on foreign relations. The author is forced into repetitions and cross references that interfere with the continuity of the story.

A more serious shortcoming of the book may well be the author's misreading of the doctrinal past of Chinese communism and of the relationship between Communist China and the Soviet Union. He shares with many others the mistaken view of Mao Tse-tung's doctrinal heterodoxy and of the alleged special role of the peasants in the Chinese Communist revolution, a myth that seems to die hard. From this mistaken view of Communist China's dif- 